\title{
Revamping Mrs. Piggle-Wiggle in Classroom Practice: Negotiating Stereotypes, Literary Language, and Outdated Values
}

\author{
Chrysogonus Siddha Malilang ${ }^{1} \mathbb{D} \cdot$ Robert Walldén $^{1}$ D
}

Accepted: 13 February 2022

(c) The Author(s) 2022

\begin{abstract}
In this contribution, we explore something rarely reported on in research on children's literature: how an old children's book is re-appropriated and altered in ongoing teaching practice. The material consists of the book used in instruction, a Swedish translation of Mrs. Piggle-Wiggle (Tant Mittiprick), and transcribed audio recordings collected throughout six weeks of teaching. Participants include a librarian, who conducted the lion's share of the discussions based on the books, two teachers, and two groups of Grade 3 students. The analysis is conducted based on Langer's theory of building literary envisionments and the concept of the "third space". The findings show that the students' initial reception of Mrs. Piggle-Wiggle, playfully articulated in the classroom discussions, is shaped by literary stereotypes of old women and connections to everyday experiences. This reception is partly acknowledged by the adults. Thus, this shows the potential of the meaning making process through join negotiation of the third space-connecting prior knowledge and experience to the book. However, the librarian's evaluations of student responses reinforce a particular didactic reading of the character as someone firm and knowledgeable, playing down the whimsical and silly characteristics of the protagonist. In reading the book aloud, the librarian made significant alterations to the text. With respect to literary language, the librarian provided numerous paraphrases and elaborations which served to support the students in making meaning of the book. More drastic alterations of the text served to avoid reinforcing outdated values, for example antiquated gender
\end{abstract}

\footnotetext{
Chrysogonus Siddha Malilang is a Senior Lecturer at the Faculty of Education and Society, Malmö University. His research interests range from children's literature to creative writing. His latest article on the Indonesian translation of Jabberwocky will be published as a part of Through Many Mirrors: Lewis Carroll's 'Jabberwocky' book (2021). He is the editor of Bookbird: A Journal of International Children's Literature.
}

\footnotetext{
Robert Walldén is an Associate Professor at the Faculty of Education and Society, Malmö University. His research in classroom work with literature, discourse-bridging interaction, and literacy practices in second-language education has been reported in journals such as $L 1$ Educational Studies in Language and Literature and Linguistics and Education.
}

Extended author information available on the last page of the article 
roles and references to physical punishment. While the paraphrases of literary terms created opportunities for negotiating the third space and learning about literary language, the sanitised reading of the book with respect to values failed to capitalise on opportunities for contextualising the book and making intertextual connections.

Keywords Classroom studies · Gender roles · Literary language $\cdot$ Text reception · Third space $\cdot$ Values

While some children's books can survive the test of time and stay relevant for decades after their initial publication, others are perceived as having aged "disgracefully"-often because of their 'outdated values'. The decision to stop publishing six books by Dr Seuss in 2021 due to allegedly racist and insensitive imagery is perhaps one of the most recent examples. Some other classic titles, such as Astrid Lindgren's Pippi Longstocking series or Enid Blyton's Noddy series, are also affected by this struggle to keep up with the shifting values. Had the publisher not intervened-by changing and adjusting them in their new editions-these series might not remain popular today. This practice of revising children's books, as Philip Nel (2017) wrote, is deemed more acceptable because on a deep level people still believe in the innocent child and our responsibility as adults to preserving this very idea. As Vanessa Leonardi (2020) argued, these changes - are initiated and taking place at the stakeholder level-to ensure the profitability of the books in the foreseeable future.

While there have been many studies of revision/rewriting in the writer/publisher level, those in the user levels_-such as parents who read to their children or teachers who use and adapt books in their teaching, is generally focused on pre-reading cullings (e.g. Stewart Lehr, 2010) where children's books are required to go through rigorous selection or censorship before being read by children or pre-reading warnings (e.g. Denzin, 2013) given by adults to dissuade children from reading books deemed as 'inappropriate'. There are a lack of studies focusing on how the users-without the publisher's intervention-attempt to bring old children's texts back from obscurity and make them more appropriate and linguistically accessible for current young readers. Our study addresses this existing gap by reporting on classroom research on the reading aloud of an American book, Betty MacDonald's Mrs. Piggle-Wiggle, in Sweden.

Regarding the questions of appropriateness, an old children's book from another country can be at tension with ideologies which have shaped values and connected educational practices in the different context in which it is read. Relevant examples from a Swedish perspective include discourses of the liberated child, consensusoriented approaches to child rearing, and subversion of traditional gender roles (e.g., Sundmark, 2021; Lynch, 2016; Russell, 2000; Waage, 2015). According to the Swedish National Curriculum (Skolverket, 2018, p. 6), schools are required to "combat gender patterns that limit the pupils' learning, choices and development". In addition, Sweden abolished the corporal punishment of children in the home as early as 1979 - a practice still legal and partly socially accepted in, for example, the UK and many parts of the US. As will be explored in the present study, such 
ideologies and values can affect the way old children's books are re-appropriated and jointly negotiated in classroom practice.

Another important contextual factor is classroom settings in Sweden becoming increasingly linguistically and culturally diverse due to substantial migration. In such classrooms, it is important to consider how the negotiation of linguistic hurdles plays a part in the re-appropriation of old books. Robert Walldén (2020; Walldén \& Nygård Larsson, 2021), in his study of adult second language education, highlighted how the social practice of reading a novel in the target language revolved to a considerable extent around the need to understand words and expressions in the book. In contrast to the frequently expressed concerns that literature has been reduced to a vehicle for language development (e.g., Carroli, 2008), the study found that the teachers' explanations of the literary language seemed central to the students' making meaning of the book. Of course, in the reading of children's books in early schooling, there is invariably considerable linguistic challenge, which also applies to many first-language students. In addition, it is important to recognise how the joint negotiation of texts in classroom settings reflects students' previous encounters with stories and characters in children's books and other media. As argued by Tørnby (2020), the reception of the narrative is always formed through dialogues between the text and the reader's background knowledge in a constructed third space.

Our general aim with the present study is to contribute knowledge about how an old children's book is re-appropriated as it is altered and jointly negotiated in ongoing teaching practice. We have particularly focused on (1) how do the students and the facilitator respond to the book with dated values?; (2) how do the facilitator's evaluative response and textual alteration transform the book?; (3) how do the discussions restrict or expand the possibilities for objectifying and making meaning of the book?; and (4) what opportunities for intertextual references are reflected in the discussions?

\section{Collaborative Response to Literature}

In this study, we draw on response theories to highlight how a classic children's book was received and reshaped in classroom discussions led by facilitators (librarians and teachers). In particular, we integrate Judith Langer's (2017) different stances in the building of literary envisionsments with Hilde Tørnby's (2020) concept of the third space.

Langer's theory of building literary envisionsments have proven useful for describing how teachers and students respond to literary texts in educational settings. Her first stance, being out and stepping into the envisionment, describes the reader forming, or reconsidering, an initial impression of the book. The second stance, being in and moving through, covers how the reader forms a deeper understanding of the text. As Sipe (1999) pointed out, child readers find literary pleasure through making connections to something they are familiar with, to further their understanding of the text, while at the same time using it to playfully enter the story. These two stances resonate with Tørnby's third space, understood as a bridge between everyday experience and the unfamiliar worlds encountered in, for 
example, an old children's book. Walldén's $(2019,2020)$ study has shown that there are rich potentials in linguistically diverse classrooms to build on the students' different experiences and perspectives. As our analyses will point to, connections to the familiar also involve prior experience of children's literature and related tropes.

Langer's third stance, stepping out and rethinking what you know, denotes instances of the book transforming the understanding of phenomena outside the book. Simultaneously, this third stance also signifies the departure from the third space and using what readers have gained within the space to make sense of the external reality. This is followed by the fourth stance, stepping out and objectifying the experience, in which the reader looks more critically and reflectively at the book as an authored piece of writing craft. According to our perspective, this stance can involve making intertextual connections between the text currently focused on and other texts the students are familiar with, to enrich the repertoire of experiences drawn on in the third space. All these stances, as Langer argued, can be promoted in joint readings and discussions.

Langer's stances have been used to analyse the students' and the facilitators' different orientations to Mrs. Piggle-Wiggle. Combined with the concept of the third space, it has been possible to highlight potentials of creative ways of making sense of literary texts, building on children's previous knowledge and experiences while stepping into and moving through the envisionment of Mrs. Piggle-Wiggle.

\section{Method and Material}

This study of the reading aloud and discussion of Betty McDonald's Mrs. PiggleWiggle (MacDonald, 1986) was conducted in a K-6 school in southern Sweden. It is located in a linguistically diverse and socioeconomically disadvantaged area. Both teachers and other staff members emphasized the need to support the students in engaging with different kinds of text and expanding their ways of using the majority language, Swedish. One of the researchers established contact with a librarian during an on-going study in the same school. After hearing the librarian's description of the planned book project based on Mrs. Piggle-Wiggle, the researcher-having expressed his interest in classroom work with literary texts-acquired permission from the librarian, the two teachers and the 40 grade 3 students (through their parents) to document the reading of Mrs. Piggle-Wiggle with ethnographically inspired methods (Fangen, 2005). Taking an observing rather than participating role, the researcher documented the classroom discussions with field notes and audio recordings $(6 \mathrm{~h})$. The students were divided into two groups (Group A and B) and received the same instruction.

All nine lessons were followed over a period of six weeks. Four of these were devoted to writing letters inspired by the reading of Mrs. Piggle-Wiggle, as highlighted in another article (see below). In the present article, we mainly draw on the first three lessons ( 2 in Group A and 1 in Group B) in which the librarian introduced Tant Mittiprick (the Swedish translation of Mrs. Piggle-Wiggle) and read the first two chapters to the students. The reading aloud of the remaining chapters was 
carried out by the teachers, for the most part unobserved by the researcher. Therefore, we will focus on the librarian's role in introducing the book.

As a part of the study, the researcher had both scheduled meetings and informal talks with the librarian. She described that she often worked closely with teachers in book projects such as the one reported on in the present article. General aims described by the librarian were students' involvement in cultural experiences and exposure to a rich, literary language. In the beginning of the study, the librarian talked warmly about Mrs. Piggle-Wiggle as an engaging, imaginative book which provided a rich context for the students to take on different roles in follow-up writing assignments. At the end of the study, the librarian talked more reservedly of the book not being her own selection, but one of the teachers' choices, due to fond memories from a previous incarnation of the project that also involved the librarian. In particular, the librarian remarked on the book being dated with respect to the current Swedish perspectives on gender. She confirmed that she did alterations in the reading of the book to mitigate this. The photocopied version of the book she used for the read-aloud was rich with markings, giving further indication of a planned approach to the alterations made.

In accordance with principles for responsible conduct in research (Vetenskapsrådet, 2017), the researcher sought informed written consent from the participating adults and the caregivers of the Grade 3 children. According to official statistics, about $50 \%$ of the school's students were from "foreign backgrounds", meaning that the students' parents, or the students themselves, were born outside Sweden. Although no potentially sensitive data was collected about individual students' language background, it can generally be stated that it was a linguistically diverse classroom shared by both first- and second-language learners that reflected the substantial migration to Sweden from, for example, the Middle-East, the Horn of Africa and other European countries.

We arrived at the research questions by consolidating the collected data and our conceptual framework, according to an abductive approach. The transcriptions are independently coded and conferred upon the different reading of the material. We found that responses and alterations oriented themselves towards literary language, stereotypes of old people in children's books, and the negotiation of discomfort in relation to outdated values. These orientations form the main sections of the presented findings. We used Langer's stances and the concept of the third space to highlight the joint negotiation of these themes, including the potentials for making further use of literary stances and enriching the experience of reading the book through the third space.

\section{Meeting Mrs. Piggle-Wiggle}

In 1947, Betty MacDonald introduced the world to an eccentric childrearing guru in her book, Mrs. Piggle-Wiggle. Through the titular character, an endearing and peculiar old lady, the book successfully reflects attitudes towards childrearing in this period, while at the same time satirising post-war America's social construction. 
As the name suggests, Mrs. Piggle-Wiggle is depicted as an unconventionally funny, even quirky, old lady. Despite being known as an expert in the handling of parenting problems, she is depicted as someone who defies the expectations of what an adult is like. As a widow, she does not conform to the "traditional family values" upheld in the American post-war period, living with the company of only a cat and a dog. Her upside-down house reflects her topsy-turvy and unorthodox approach to various problems and life in general. The un-adultlike characteristics indicated by her way of living are what made children in the neighbourhood comfortable playing with her-while also doing substantial housework on her behalf. The affinity between Mrs. Piggle-Wiggle and the children invokes the concept of intergenerational solidarity in children's literature (e.g., Sundmark, 2021; Joosen 2015), with an elderly character as an interdependent ally against the seriousness of the adult world and normativity.

In contrast to Mrs. Piggle-Wiggle's playfulness, the other adults in the neighbourhood are portrayed satirically. In the only study about the book that we have knowledge of, Mills suggests that it is as if MacDonald wanted to caricature of the overemphasising of traditional family values. All the mothers are depicted as dedicated homemakers, stay-at-home women who spend their time in club meetings and waiting for their children to come back from school. The fathers, on the other hand, do undetermined office work, commuting by train with briefcase in hand.

The chapters in Mrs. Piggle-Wiggle generally follow the same pattern, started by an undesired behaviour in a child. The parents become exasperated by this behaviour to the point that the desperate mother tries to find a solution by calling the other mothers. This generally leads to preposterous maternal interactions and braggingcontests, ending with a recommendation to contact Mrs. Piggle-Wiggle. This rendering as the advice-giver makes Mrs. Piggle-Wiggle fit in the ageist trope of the wise mentor (Joosen, 2015). At the same time, the titular heroine's position as the last resort also cements her status as the "wise woman" (Bramwell, 2009)—an independent-minded person often associated with magic who lives on the edge of communities which fear but also need her. At the same time, she also fits in one of Joosen's ageist tropes-depicting the elderly as the wise mentor.

The chain of events continues with the titular heroine becoming a calming voice for these confused mothers, providing relief through her complimentary remarks on the supposedly problematic children. While retaining her positivity, Mrs. PiggleWiggle proceeds by proposing her exaggeratedly silly "cures". Her use of the term "cures", as Claudia Mills claims (2001, p. 9), actually reflects the development of child psychology at that time, and the shift away from a moral to a medical perspective. This leads to the understanding of "misbehaviour" as a curable disease.

In the book used in this study, all the cures closely reflect a behaviouristic perspective in which parents "train" or condition their children. Children are given more freedom to do what they want, while parents are encouraged to be permissive and worry less. Children are expected to learn from the consequences of their "misbehaviour". Flexible parenting is clearly championed over stringency.

It is interesting to contrast Mrs. Piggle-Wiggle's remedial approach to unruly children with Astrid Lindgren's books about Pippi Longstocking (1946) due to their cultural significance in Sweden. In Lindgren's seminal series, contemporary 
with the Mrs. Piggle-Wiggle series, unruliness and thwarting of adult authority are celebrated. As noted by Lynch (2016) and Russell (2000), these books are emblematic for Sweden as a nation concerned with counter-acting traditional gender roles. Although both Mrs. Piggle-Wiggle and Pippi Longstocking rely on absurdist comedy for purposes of satire, Lindgren is more explicit in making the adults bear the brunt of the mockery. As argued by Sundmark, conflicts and re-distribution of power between children and adults are central also in Lindgren's Emil series (1963-1997), even though the titular character, unlike Pippi, usually receives punishment for his misdeeds. Another relevant, although more low-key example from the Swedish canon of children's literature are Gunilla Bergström's Alfie Atkins books in which the protagonist grows up in the sole care of his loving and-in domestic mattersmindful father. Waage (2015) has noted that the books represent values of equality and consensus-oriented parenting in which problems are best solved with discussions. Issues of gender and parenting actualized by the read aloud of Mrs. PiggleWiggle will be of key interest in the analysis.

As this research deals mainly with the Swedish version of Mrs. Piggle-Wiggle, it is important to observe the changes in the translation. As Leonardi (2020) has noted, there are greater liberties of text manipulation in translating for children, due to different expectations of child readers in every culture. From that point of view, it is not unexpected for the titular character Mrs. Piggle-Wiggle to be transformed into Tant Mittiprick (literally translated as "Aunt Spot-On, or, according to the current use of "tant", "Old Lady Spot-On"). Consequently, this translation creates a possible space for shift in interpretation, from someone funny and amicable (Piggle-Wiggle) into a potentially authoritative, always-right lady (Mittiprick). The Swedish translation also retains Maurice Sendak's illustrations instead of using the considerably newer illustration by Alexandra Boiger. How Sendak's version may contribute to the interpretation and understanding of the book will be discussed in the coming analysis.

Previous publications based on the same material (Walldén, 2021) highlighted how the reading of Mrs. Piggle-Wiggle was followed up by a written assignment in which the students were expected to assume the role of the titular character and write letters containing advice to parents of misbehaving children. In this process of writing pedagogy, directed and supported by the librarian and the teachers, Mrs. Piggle-Wiggle was construed as an authoritative expert rather than quirky or mysterious. This reception of the book merits a close look at how it was initially presented to, and received by, the students.

\section{Students' Initial Impressions: “A Grumpy Old Lady Who Is Happy...”}

Sendak's illustrations and the name change into Tant Mittiprick may be indirectly responsible for shaping the students' first impression of Mrs. Piggle-Wiggle. He portrayed Mrs. Piggle-Wiggle as an old lady who wears her hair tightly on the back of her head, though according to the book "[s]he usually wears it [her hair] on top of her head in a knot, unless someone has been combing it...". 
Thus, it is not unexpected that one of the students, when shown one of the illustrations, perceived the titular character as "old and angry" and "a child hater" when the librarian asked them about their first impression of Mrs. Piggle-Wiggle. One student even went as far as using the term kärring (old hag) to describe her. This echoes one of Joosen's ageist tropes in which old people are seen as the decline narrative-where growing old is seen as an unpleasant ride downhill that instils bitterness. Another student took up and elaborated this trope rather playfully by making his/her own story about Mrs. Piggle-Wiggle.

F: She was old and she often forgot stuff. But I don't think she has any disease or so. Second, she did not go to school. She did not learn how that you should act like this. What's it called. And, like, that human noses do not grow on flowers and the like. I mean, her imagination is too wild.

Another student, while still admitting that Mrs. Piggle-Wiggle looked grumpy, added a different character to describe her.

A: I think she looks like a grumpy old lady who is happy.

Teacher 1: Happy. A grumpy old lady who is happy?

A: Yes, an old lady who is supposed to be grumpy, but she is happy.

As opposed to the complete bitterness implied in declined narrative, Mrs. Piggle Wiggle was characterised as the amalgamation of traits commonly associated with the elderly (grumpy) and that associated with the children (happy). Similar to Joosen's discussion of Guus Kuijer's The Book of Everything, the child (reader) forges an alliance with the elderly through the shared childlike quality. While Joosen's argument took the stance of the elderly trying to "re-embody their former childlike selves in order to bond with the young", what took place in this student's reaction shows the opposite, if not reciprocal, process. This also demonstrates the child reader's attempt to go further into the text and, as Sipe has pointed out, find literary pleasure through making connections to something they are familiar with, including themselves, to further their understanding of the text while at the same time using it to playfully enter the story. In other words, it is a way to step into the envisionment of the book (Langer, 2017).

Both the teachers and the librarian, however, did not allow for all of these playful descriptions of Mrs. Piggle-Wiggle to go further. Instead of putting themselves in the middle of the play, the teachers and the librarian tended to repeat the characteristics that they considered correct. The students' opinion was rendered less significant at the end of the discussion, when the librarian started by reinforcing her own interpretation of Mrs. Piggle-Wiggle.

Librarian : As you can see, she is a lady who's a bit old. She is happy but she is also very firm and clear.

In doing so, the librarian did not build on students' play with the tropes and their interpretations as resources for entering and moving through the envisionment. Instead of acknowledging the building up to puer senex - the shared similarities between children and the elderly against the adult normativity, she instead 
positioned Mrs. Piggle-Wiggle as part of adult normativity. By saying "a bit old" (en lite äldre tant), she plucked away the titular character from the elderly group and categorised her as adult. The 'happy' quality in Mrs. Piggle-Wiggle that demonstrates the infantilised senior is superimposed through 'firm and clear'-a more authoritative trait commonly associated with adult normativity. By doing so, she downplayed the stereotypes of elderly characters that the children seemed to draw on as a resource for entering the envisionment and making sense of the book. Since the librarian foregrounded her own reception of Mrs. Piggle-Wiggle, likely aligning with her goals of the writing exercise which followed the reading (see below), this interaction seemed different from the more playful one highlighted earlier which showed more receptiveness to the children's creation and navigation of the third space.

The librarian's take on Mrs. Piggle-Wiggle is further evident in a writing assignment in which the students engage in role-play by writing letters from Mrs. PiggleWiggle to parents frustrated by their children's behaviour. This is illustrated in the excerpt below, in which the librarian gives feedback to a student's text.

Librarian: Do you remember what we talked about yesterday? When you are Mrs. Piggle-Wiggle, you're not like the parents, right? Then you act in a different way. What were you to think about in your answer? /.../

Student: Well, you, like, write the solution but you are firm in what you are writing.

Librarian: Mm. Why do you use a firm voice when you write? As Mrs. PiggleWiggle?

Student: Mrs. Piggle-Wiggle's like that because she knows everything. Cause she is smart.

Librarian: Exactly. She knows what's going on and she's self-assured. Her methods always work, right?

This assignment enforces the "Mrs. Spot-On" incarnation of Mrs. Piggle-Wiggle over the silly and exaggerated characteristics which could be retrieved by a different reading of the book. Instead of opening a more playful space where students are free to explore different interpretations, the librarian took a more didactic stance and limited the opportunities to identify and work creatively with the parodical stereotypes as a way to step into and move through the envisionment of the book. In this attempt to direct the students' learning process, this limited the potential of using the third space (Tørnby, 2020) to learn and grow by merging the world of the children and the new, unfamiliar, world encountered in the children's book.

\section{Coming to Terms with Mrs. Piggle-Wiggle: A Book Character or Someone's Grandma?}

The third space, further defined by Tørnby (2020, p. 62), serves as child's bridge to enter an unfamiliar space with an atmosphere and rules different from "home". It is in this bridging space that familiar concepts are imposed upon strange and alien things to ensure the comfort and safety of their encounters, 
while simultaneously making sense of them. The construction of this space could be observed in the discussion of the book, where the students projected people familiar to themselves onto the characters in the book. What they perceived from observing these people became the basis on which to characterise and explain the new people they encountered in the text.

Two students even compared Mrs. Piggle-Wiggle to one of their teachers on the basis of age and drew the conclusion that these two supposedly unrelated figures shared the same characteristics. Their perceptions of this specific teacher are thus superimposed on the textual characterisation of Mrs. Piggle-Wiggle, creating a playful description.

Student: She looks fifty-year old

Teacher: What did you say? A fifty-year old?

Student: She is as old as [name of the teacher]

Teacher: Okay

Student: It looks like she is baking something. Then it became too hot so she became so angry so she just ran. (pause) She is not angry.

The fact that the teacher confirmed the students' suggestions and asked followup questions can be seen as the relegation of power. The lack of enforcement of her own perspective signals the permission for them to enter the third space and play. On the other hand, it is obvious that the students tried to encapsulate their teacher in Mrs. Piggle-Wiggle in order to make sense of the character, as part of stepping into the envisionment of the children's book (Langer, 2017).

This newly created horizontal power structure allowed the creation of "playworld" (Lindqvist, 1995; You \& Malilang, 2017)—where adults and children play together in a sphere ruled by children. It is within this sphere that the children are allowed to explore the unknown without being bound by the adults' normativity normally encountered in the real world. It is through play in this space that the students learn how to characterise Mrs. Piggle-Wiggle, by negotiating their perception of the characters and their background knowledge of the teacher referred to.

The same process also applies when the students tried to make sense of events in the book. One example is when they discussed why parents in the book were frustrated because their son refused to clean his room.

Student: They can just say that if he doesn't clean the room, he is not allowed to go out and watch TV and so on. I mean, no TV and playing out before he has cleaned the room. My father usually does that. I am not allowed to go before I cleaned my room. Everywhere, under the bed...

We can see from the dialogue that this student recalled an experience of dealing with his father. He brought his own experience from a familiar setting (home) to explain the action of the father in the book. This process of reflection becomes the bridge connecting the familiar to the unfamiliar, enabling the student to move through the literary envisionment (Langer, 2017). The characters in the book were consequently transposed and superimposed onto people around the students, 
their fathers, their mothers, their grandmothers, or other relatives. By doing so, the book is also further modernised, plucked from its original 1940s context into a more present-day setting bridged by these familiar references from the students' everyday experiences.

\section{Transformations of Literary Language: "Furious, that is-Raging Angry"}

As a book written in 1940s, Mrs. Piggle-Wiggle contained literary language unfamiliar to the students. Instead of seeing this as a drawback, the librarian-when asked about the choice of book-mentioned how reading Mrs. Piggle-Wiggle would be a way for the students to encounter literary language, stressing how a word such as purple would be unknown to many of them (in the Swedish version translated as purpur, a quite rare word rather than the more common lila).

Before reading the first two chapters, the librarian showed a selection of words and gave short explanations while pointing out that the book was written in the forties. In the first chapter, many of the words chosen served to describe Mrs. PiggleWiggle, for example dwarf, fairy and knack-a Swedish toffee describing Mrs. Piggle-Wiggle's smell. The librarian was quite precise in her explanations, often using both paraphrasing and references to presumed prior knowledge, describing a fairy as "a short figure with wings ... like Tinkerbell' and knäck as "something you know about if you celebrate Christmas, like a chewy fudge with almonds which is boiled". With a word like switch, she pointed to a switch in the classroom and clarified that it could also mean "a larger switch which you can use to turn off the electricity entirely".

As shown in the below transcript, in explaining forget-me-not (förgätmigej), she mentioned the English name before translating it to everyday Swedish ( $\mathrm{glöm} \mathrm{mig}$ inte) and bringing attention to the antiquated verb (förgät) used in the Swedish word ("old Swedish... förgät means forget"). Before, she had offered the simple paraphrase 'a blue flower'.

Librarian: [Förgätmigej]. It is a blue flower. In English you say forget-me not.

Don't forget me. Old Swedish. [Förgät] means forget. And "me not". Don't forget me.

In addition, she paraphrased the antiquated negation "ej" forming part of the Swedish word, with the common "inte" (not). She approached making the literary language available to the students in a planned way, often giving them several opportunities to make sense of it. Her connecting of the literary language to familiar and more relatable concepts can be seen as paving the way to the opening of a third space to enter and move through the envisionment.

During the reading of the book, the librarian also made paraphrases of words to clarify their meaning: "furious, that is raging angry". However, on some occasions she just offered a paraphrase. For example, in reading about the "Cruel Queen" persona adopted by Mrs. Piggle-Wiggle playfully instructing a girl to clean thoroughly in Chapter 1, the character received the more everyday epithet mean (elak), 
possibly due to the actual translation, grym, often being used as a positive evaluation in young people's speech. Similarly, she substituted feeble (klen) and hysterical (hysterisk)—describing children in the many phone-calls between exasperated and boastful mothers in the book-with more everyday varieties: weak (svag) and crazy (galen).These words are likely to be more familiar to the students, while also being more general and less derogatory. Also, the axe-wielding children referred to above were chopping firewood (ved) rather than kindling (tändved). The alterations were marked on the librarian's copied version of the book, further underscoring the planned approach to the language of the novel. This reflects what Leonardi (2020) argues on how the translator (or in this case, the intralingual translator-the one translating within the same language through rewriting or rewording) feels they have the permission to manipulate and abridge the text according to his/her expectation of the child reader. The librarian likely deemed it necessary to substitute some of the literary language with more everyday wording that she assumed the students were more familiar with so as not to belabour the reading with too many explanations. In addition, the alterations might reflect a general desire to modernise the text, in this case by substituting the occasionally archaic language for more contemporary usage.

Overall, these linguistic alterations seemed to serve the purpose of facilitating the students' stepping into the envisionment of Mrs. Piggle-Wiggle and moving through it. Moreover, the explanations provided made it possible for the students to contrast literary language with everyday equivalents through the creation of the third space-an opportunity which was removed when the librarian substituted words like feeble and cruel. Overall, the in-context explanations of the word seemed conducive to learning about language (Stance 3 ) while, at the same time, experiencing and making meaning of the book (Stance 2).

\section{Transformations of Gender: Girls Baking Cookies with Their Male Friends}

Several of the alterations made by the teacher did not have anything to do with negotiating literary language: rather, they concerned the values transmitted in the book which are perceived as outmoded in Sweden. This is in line with Shoshana Magnet and Catherine-Laura Dunnington's research (2020) on the discomfort felt by educators alike in discussing unusual topics that may bring about uncomfortable feelings. As a result, "the impulse for comfort bumps up against the impulse for the kinds of discomfort that are necessary for rethink, reconsider, and alter perception" (Whitelaw, 2017, p. 34).

Indeed, the librarian in this study made frequent alterations related to gender in her reading of Mrs. Piggle-Wiggle. In her version, four war-paint wearing children were chopping wood by Mrs. Piggle-Wiggle's house, not four boys, and not only Mrs. Prentiss was exasperated by her child's refusal to clean his room, but also $M r$. (herr) Prentiss. Sometimes, these alterations seemed slightly overdone. In the first chapter, two girls baking cookies were accompanied by their male friends (killkompisar) despite a pie-baking boy appearing in the very next sentence. Also, witnessing 
the miraculous effect of Mrs. Piggle-Wiggle on his daughter's housekeeping, $M r$. Robertson (replacing Mrs. Robertson) perplexingly addressed himself by calling out to "Mary Lou's father". After the initial lessons reading the book, the librarian commented critically on it being "dated" with regard to gender, referring specifically to a description of a girl combing Mrs. Piggle-Wiggle's hair, a depiction of role playa queen and her royal hairdresser-much abridged in the librarian's adaptation. It seems clear that she wanted to avoid perpetuating antiquated gender roles.

A different, and, as far we could see, singular, alteration occurred in the description of Mary Lou, the first child being "cured" by Mrs. Piggle-Wiggle. In the librarian's version, she is succinctly described as "eight-year-old", leaving out the elaboration "and quite fat" (och ganska tjock). However, in the librarian's reading, Mary Lou was still allowed to eat eight cookies offered by Mrs. Piggle-Wiggle while sobbing through her story of cleaning dishes at home. The librarian was likely not comfortable with the body-shaming associated with comedic functions of overweight characters, and children in particular.

The alterations with respect to gender and body-image can be seen as a way to navigate discomfort arising in the reading of Mrs. Piggle-Wiggle due to tensions between outdated values in the book and the present-day context it is read in, involving the responsible teaching and transmission of values for children. In this case, however, avoiding discomfort also meant missing out on the potential for contrasting aspects of the book perceived as outdated with the present-day context and other texts from different time periods the students are familiar with. We will elaborate on these potentials, relating to the creation the third space and objectifying the experience of reading the book, in the closing discussion.

\section{Dealing with Discomfort: “It Sounds Like It Is Something Funny. But It's Really Not"}

This navigation of discomfort became even more evident when an offhand remark during one of the phone conversations between mothers in the book sparked a lengthy discussion (excerpted below). It concerned a mother casually referring to "having smacked" (the translator avoiding the more precise Swedish term for spank, smiska) her daughter seven times since breakfast. Interestingly, the librarian did not alter this part but called attention to it and asking the children to keep in mind that "the book was written in England [sic] in the 50's ... [w] hen smacking children was allowed". Furthermore, she commented that it was written "like it was something funny ... but it's really not". She also stressed that it is "absolutely forbidden" to smack children in Sweden. This elaboration by the librarian is interesting, since it shows another approach to negotiating discomfort in the book while also being one of few occasions when she objectified the book by evaluating it and pointing out the context it was written in. The librarian's explanation was followed by a highly interesting question from one of the students. The entire exchange is shown in the transcript below. 
Librarian: Well, here we have a mother smacking her child. We must keep in mind that this book was written in England in the 50's. And then it was allowed to smack children. And in this book, it sounds like it is something funny. But it's really not. In Sweden, it is absolutely forbidden. To hurt a child in any way. /.../ What did you say?

Student: But can you, like, write it in books?

Librarian: Well, in those days, when it was written as if it was comical. Like as if it was something wacky. But there's nothing wacky or fun about it.

Student: But if you can't hit children, can you still write.

Librarian: We could talk about this when we're done reading. Let's do that.

The student wanted to know if writing about smacking children in books was allowed, seemingly stepping out of the envisioning to reconsider what they knew about literature: "if you can't hit children, can you still write?" In answering the question, the librarian repeated the different context it was written in and reiterated her moral stance on corporal punishment. She also suggested that they followed up this discussion after completing the reading of the book.

However, instead of taking the opportunity for engaging in a deeper discussion about values in literature in relation to original and present-day contexts, the librarian chose a different tack. Providing further evidence of the discomfort arising when reading about the smacking of children, the librarian brought up BRIS, a well-known national children's rights organisation providing a helpline for children who experience abuse in their home environment. In the ensuing discussion, focusing on BRIS, the novel became peripheral, limiting the possibilities of learning about literature (Langer's Stance 3) and objectifying the experience of reading the book (Stance 4).

The librarian herself expressed surprise at the passage in the book. If she had noted it in her pre-reading, it seems likely that she would have omitted or altered it. In fact, she did alter the conclusion of the relevant phone conversation: the mother merely would call Mrs. Piggle-Wiggle "after talking with Susan", instead of as soon as having spanked Susan. However, this accidental encounter with discomfort provided the spark that facilitates critical thinking, opening a space for the reconsideration of self, belief, and the current context of the world (Magnet \& Dunnington, 2020). Other possible approaches for dealing with discomfort will be discussed presently.

\section{Conclusions}

The aim of the present article was to contribute knowledge about how the book Mrs. Piggle-Wiggle was re-appropriated in classroom practice in light of the lack of previous studies taking a user level perspective on alterations of children's books (cf. Stewart Lehr, 2010; Denzin, 2013). The findings have shown that the librarian, in the read-aloud, made substantial alterations to facilitate comprehensions of literary language, mitigate antiquated perspectives on gender and parenting and promote a specific pedagogical agenda. Of these, the alterations of literary language seemed least invasive as the librarian retained the wordings of the Swedish 
translation-containing words and expressions likely to prove difficult for the students - while providing exemplifications and paraphrases aimed at making the text comprehensible to the students in the linguistically diverse classroom. Assuming the role of intralingual translator of children's literature (Leonardi, 2020), the librarian's planned approach to language probably supported the students in entering and moving through the envisionment. More implicitly, and aligned with the librarian's expressed ambitions, it also provided opportunities for learning about literary language (Langer's Stance 3). This arguably promoted the potential for learning and development in the third space, as unfamiliar literary words were put in relation to known concepts (Tørnby, 2020). However, aside for mentioning that the book was written in the forties, the teacher did not explicitly point out the language as literary language-something which could have created opportunities for objectifying the experience of reading the book (Langer's Stance 4). Making the input comprehensible, and thus reducing judgemental, satirical and archaic aspects of the language, seemed to be prioritised over a more analytical approach.

In the negotiation of stereotypes, the book was more substantially transformed. In line with the librarian's aims to help the students writing authoritative letters, possibly in combination with the more authoritative persona invoked by the Swedish translation of the titular character's name ("Aunt Spot-On"), Mrs. Piggle-Wiggle was construed as "firm" and "strict". This seemed to limit the possibilities to explore the intertextual references and familiarity with literary tropes likely underlying the students' contributions of her being "grumpy" or "having too much imagination". The apparent disregard of the silliness of Mrs. Piggle-Wiggle's proposed cures also downplays the parody arguably achieved in the book with respect to the behaviour of the adults (Mills, 2001; see also Sundmark, 2021). In addition, the characteristics of adult normativity at least partly ascribed by the librarian and the teachers to Mrs. Piggle-Wiggle de-emphasized the intergenerational solidarity present in the book. Thus, the findings have pointed to the potential in using students' experiences of literary tropes (see Joosen, 2015) to make meaning of the book analytically.

The findings have also shown that the librarian made significant alterations for the book to comply with ideologies and values attached to questions of gender and parenting in Sweden (Lynch, 2016; Skolverket; Waage, 2015). Notably, stereotypical gender roles were re-balanced in a sometimes hyper-corrective way. In relation to the casual mention of corporal punishment, the librarian instead chose to point out the context the book was written in while underscoring how the passage does not hold up to modern values. This entailed a more analytical stance to the text which could be conducive to negotiating the presumed unfamiliarity with corporal punishment. From this perspective, a student's question about what you "can write in books"- - unanswered by the librarian-provided a missed opportunity to discuss how books can be appraised in relation to their context in a more in-depth way. This response could also be seen as adult's (in this case, the librarian's) fear of children's metareflection on the craft of writing as a medium for expressing taboos and a way to question norms through anarchic, playful narrative. By doing so, the librarian relegates children's reading into the literal, perhaps avoiding critical thinking and discernments that manifest as playful responses. Moreover, the fact that these linguistically diverse students-doubtless having experiences of children's book and stories 
from different cultural contexts-seems not to be taken into account, thus missing the potential for further playful and exploratory intercultural discussion about the literary text.

Overall, the findings underscore the potential value of an intertextual approach to the joint reading of the book, in which the students' reactions to the book and its characters are explored in an open-ended dialogue. In Langer's terms, it would involve less emphasis on the adults' envisionment of the book, involving a certain view of Mrs. Piggle-Wiggle and outdated values in the book, and being more sensitive to the students' prior knowledge and experiences, underpinning their own envisionments to create and enrich the potentials of making meaning through the third space. This could include inviting students' experiences of, for example, gender-typical behaviour and relationships between children and adults in other stories from different time periods. In the words of Magnet and Donnington (2020), it would also involve tolerating the necessary discomfort of encountering values and practices perceived as outdated. Our hope is that this inquiry into this pedagogical re-vamping of Mrs. Piggle-Wiggle in a librarian's read-aloud can inspire further studies into how old children's books are re-shaped by norms, values and agendas in specific educational practices. In addition, we believe it can inform such practices to provide opportunities for children to take different stances to the text material and make use of prior knowledge and experiences of stories and characters in children's books.

Author Contributions All authors contributed to the study conception and design. The materials preparation and analysis were performed by both authors, but the data collection was performed only by Robert Walldén. All authors read and approved the final manuscript.

Funding Open access funding provided by Malmö University. No funding was received for conducting this study.

Availability of Data and Material All data and materials have been processed in accordance to GDPR and research requirement.

\section{Code Availability N/A.}

\section{Declarations}

Conflict of interest The authors have no relevant financial or non-financial interests to disclose.

Ethical Approval The research has been done in adherence to Swedish Vetenskapsrådet's (2020) principles, General Data Protection Regulation (GDPR), and Malmö University's ethical guidelines.

Consent to Participate All participants in this research have been informed about the study purpose and their roles in it. All of them have gave consent to participate and in the case of minors, the consent of their parents/guardians has been acquired.

Consent to Publication Both authors, Chrysogonus Siddha Malilang and Robert Walldén, give their consent for publication.

Open Access This article is licensed under a Creative Commons Attribution 4.0 International License, which permits use, sharing, adaptation, distribution and reproduction in any medium or format, as long as 
you give appropriate credit to the original author(s) and the source, provide a link to the Creative Commons licence, and indicate if changes were made. The images or other third party material in this article are included in the article's Creative Commons licence, unless indicated otherwise in a credit line to the material. If material is not included in the article's Creative Commons licence and your intended use is not permitted by statutory regulation or exceeds the permitted use, you will need to obtain permission directly from the copyright holder. To view a copy of this licence, visit http://creativecommons.org/licen ses/by/4.0/.

\section{References}

Bramwell, Peter. (2009). Pagan Themes in Modern Children's Fiction. Basingstoke: Palgrave Macmillan. Carroli, Piera. (2008). Literature in Second Language Education: Enhancing the Role of Texts in Learning. London: Continuum.

Denzin, Jen. (2013). Boundaries for Contemporary Literature: The Role of Censorship and Choice. Journal of Adolescent and Adult Literacy, 57(1), 7-11. https://doi.org/10.1002/JAAL.213.

Fangen, Katrine. (2005). Deltagande Observation (Participant Observation). Stockholm: Liber

Joosen, Vanessa. (2015). Second Childhoods and Intergenerational Dialogues: How Children's Literature Studies and Age Studies Can Supplement Each Other. Children's Literature Association Quarterly, 40(2), 126-140. https://doi.org/10.1353/chq.2015.0016.

Langer, Judith A. (2017) Litterära föreställningsvärldar: litteraturundervisning och litterär förståelse (Envisioning Literature: Literary Understanding and Literature Instruction). Trans. Anna Sörmark. Gothenburg: Bokförlaget Daidalos AB

Leonardi, Vanessa. (2020). Ideological Manipulation of Children's Literature Through Translation and Rewriting: Travelling Across Times and Places. Cham: Palgrave Macmillan.

Lynch, Lisa. (2016). Where Are All the Pippis?: The Under-Representation of Female Main and Title Characters in Children's Literature in the Swedish Preschool. Sex Roles, 75, 422-433. https://doi. org/10.1007/s11199-016-0637-7.

Lindqvist, Gunilla. (1995). The Aesthetic of Play: A Didactic Study of Play and Culture in Preschools. Pennsylvania: Coronet Books Inc.

MacDonald, Betty. (1986). Tant Mittiprick (Mrs. Piggle-Wiggle), illus. Maurice Sendak. Trans. Eva Imber-Liljeberg, Stockholm: Barnboksförlaget Läseteket.

Magnet, Shoshana, and Dunnington, Catherine-Laura. (2020). Necessary Discomfort: Three Preschool Classrooms Break Open The Heart and the Bottle and Sit with Hard Feelings. Bookbird: A Journal of International Children's Literature, 58(1), 1-14. https://doi.org/10.1353/bkb.2020. 0009.

Mills, Claudia J. (2001). Powders and Pills to Help Cure Children's Bad Habits': The Medicalization of Misbehavior in Mrs. Piggle-Wiggle. Children's Literature Association Quarterly, 26(4), 188-197. https://doi.org/10.1353/chq.0.1564.

Nel, Philip. (2017). Was the Cat in the Hat Black? The Hidden Racism of Children's Literature and the Need for Diverse Books. New York: Oxford University Press.

Russell, David L. (2000). Pippi Longstocking and the Subversive Affirmation of Comedy. Children's Literature in Education, 31(3), 167-177.

Sipe, Lawrence. (1999). Children's Response to Literature: Author, Text, Reader, Context. Theory into Practice, 38(3), 120-129. https://doi.org/10.1080/00405849909543843.

Skolverket. (2018). Curriculum for the compulsory school, preschool class and school-age educare. https://www.skolverket.se/getFile?file=3984

Stewart Lehr, Susan. (2010). Literacy, Literature and Censorship: The High Cost of No Child Left Behind. Childhood Education, 87(1), 25-34. https://doi.org/10.1080/00094056.2010.10521435.

Sundmark, Björn. (2021). "You and I Alfred": Intergenerational Solidarity in the Emil Series. In Jystyna Deszcz Tryhubczak and Zoe Jaques (Eds.), Intergenerational Solidarity in Children's Literature and Film, (pp. 31-43). Jackson, MI: UP of Mississippi.

Tørnby, Hilde. (2020). Picturebooks in the Classroom. Oslo: Fagbokförlaget. 
Waage, Lars Rune. (2015). The Apocalypse of Scandinavian Social Democracy? A Reading of Johan Harstad's Novel Hässelby. Scandinavian Studies, 87(2), 234-254. https://doi.org/10.1353/scd. 2015.0009.

Walldén, Robert. (2019). Med fokus på ord, uttryck och språklig stil: Ett betydelseskapande litteraturarbete i grundläggande vuxenutbildning. Pedagogisk forskning i Sverige, 24(3-4), 36-61.

Walldén, Robert. (2020). Interconnected Literacy Practices: Exploring Work with Literature in Adult Second Language Education. The European Journal for Research on the Education and Learning of Adults, 11(1), 45-63. https://doi.org/10.3384/rela.2000-7426.rela9202.

Walldén, Robert. (2021). "Den här föräldern smörjer tant Mittiprick litegrann": Integrerat läsande och skrivande under ett litteraturarbete i årskurs 3 (This Parent is Buttering Up Mrs. Piggle-Wiggle a bit: Integrated Reading and Writing in Working with Literature in Grade 3). Forskning Om Undervisning Och Lärande, 9(1), 5-30.

Walldén, Robert, and Nygård Larsson, Pia. (2021). Negotiating Figurative Language from Literary Texts: Second-Language Instruction as a Dual Literacy Practice. L1 Educational Studies in Language and Literature, 21, 1-30. https://doi.org/10.17239/L1ESLL-2021.21.01.08.

Whitelaw, Jessica. (2017). Beyond the Bedtime Story: In Search of Epistemic Possibilities and the Innovative Potential of Disquieting Picturebooks. Bookbird: A Journal of International Children's Literature, 55(1), 33-41. https://doi.org/10.1353/bkb.2017.0004.

You, Chengcheng, and Malilang, Chrysogonus Siddha. (2017). Playtime in Playworld: How Children Learn to Rule. In Christopher Kelen and Björn. Sundmark (Eds.), Child Autonomy and Child Governance in Children's Literature: Where Children Rule, (pp. 218-230). New York: Routledge.

Vetenskapsrådet. (2017). Good Research Practice. Stockholm: Vetenskapsrådet. https://www.vr.se/downl oad/18.5639980c162791bbfe697882/1555334908942/Good-Research-Practice_VR_2017.pdf

Publisher's Note Springer Nature remains neutral with regard to jurisdictional claims in published maps and institutional affiliations.

\section{Authors and Affiliations}

\section{Chrysogonus Siddha Malilang ${ }^{1}\left[\right.$ Robert Walldén $^{1}[$}

\section{Chrysogonus Siddha Malilang}

chrysogonus.siddha.malilang@mau.se

Robert Walldén

robert.wallden@mau.se

1 Faculty of Education and Society, Malmö University, Malmö, Sweden 